\title{
Remediation of the Old Ecological Load in the Protected Area of the Morava River - Re-abandonment of the Oil and Gas Production Wells
}

The Mining-Geology-Petroleum Engineering Bulletin (C) The Author(s) 2015 UDC: 622.243 DOI: 10.17794/rgn.2015.1.4 preliminary communication

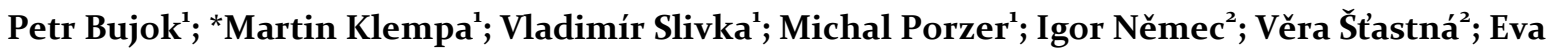 Smejkalová'; Jaroslav Zdvořák ${ }^{3}$}

${ }^{1}$ Faculty of Mining and Geology, VSB - Technical University of Ostrava; 17. listopadu 15, 70800 Ostrava Poruba, Czech Republic ${ }^{2}$ Palivový kombinát Ústí, s.p.; Hrbovická 2, 40339 Chlumec, Czech Republic

${ }^{3}$ Faculty of Civil Engineering, VSB - Technical University of Ostrava; 17. listopadu 15, 70800 Ostrava Poruba, Czech Republic

\begin{abstract}
The presence of the former oil and gas producing wells that are or can be improperly abandoned creates a possible environmental hazard in terms of contamination of the groundwater and soil in the present. In the area of the Czech Republic, specifically in South Moravia part, which has a long oil and gas production history, plenty of such wells can be found. Finding out the information about their abandonment in archives is often very demanding (sometimes even impossible). During various survey works and re-abandonment attempts it was found out that many wells are originally abandoned improperly, insufficiently or not at all. The occurrence of such wells is not just potential but also very actual hazard for the cultural landscape of the South Moravia, especially for aquifers, agriculture and natural protected areas of national significance. This paper is focused on the possibility of the definitive abandonment of this particular ecological load. The proposed method was verified in laboratory conditions and in the field. It is now a standard form of the reabandonment of oil and gas wells without precise localization in the South Moravian oil fields.
\end{abstract}

\section{Keywords}

Oil and nature gas; well liquidation; ecology; fracturing

\section{Introduction}

Statutory corporation Palivový kombinát Ústí (PKÚ) was commissioned by the resolution of the Czech government (no. 713 in year 2007) to remediate the ecological loads generated by the oil and natural gas production activities for which the state bears liability. These ecological loads (EL) are situated in the south-eastern part of the Czech Republic (South Moravia - see Fig. 1) and they originate in the period between the years 1925-1965. PKÚ carries out the remediation activities of mentioned EL in the area since 2010. In our study the term EL includes the exploration wellbores and the oil and natural gas production wells that were improperly or insufficiently abandoned, along with the remaining downstream equipment or upstream facilities and also the contaminated ground due to the oil spills or other related fluids leakage. The vertical depth of the wellbores spans from $115 \mathrm{~m}$ up to the $2667 \mathrm{~m}$ (Čižmář, 2004; D̆urica, 2011).

The remediation activities take place at the area of about $28 \mathrm{~km}^{2}$ which is located in the Hodonín and Břeclav districts. Whole affected land is utilized for farming and the areas with the dense concentration of the ELs (especially in the Hodonín vicinity) are ornithological interesting location, part of which is the nature reserve Skařiny. There is also situated the Mikulčice village with famous archaeological location Slavic hill fort. The vast majority of the area also belongs under the biosphere reservation Dolní Morava. The area of interest is part of the nature protection areas NATURA 2000, which form a complex of forests and marshes with habitats of many flora and fauna species. The greatest number of old ELs is found in the floodplain of Morava River, which forms a wildlife corridor of the national significance.

After the initial research of all possible sources of information it was found, that total of 607 wells (potential ELs) are situated in the protected area of the natural groundwater accumulation called "the Quaternary sediments of the Morava 
river". Since 2010 the re-abandonment works are conducted according to the previously developed realization projects, 6 of which are funded by the Ministry of Finance of the Czech Republic. The re-abandonment works are expected to be finalized in 2017.

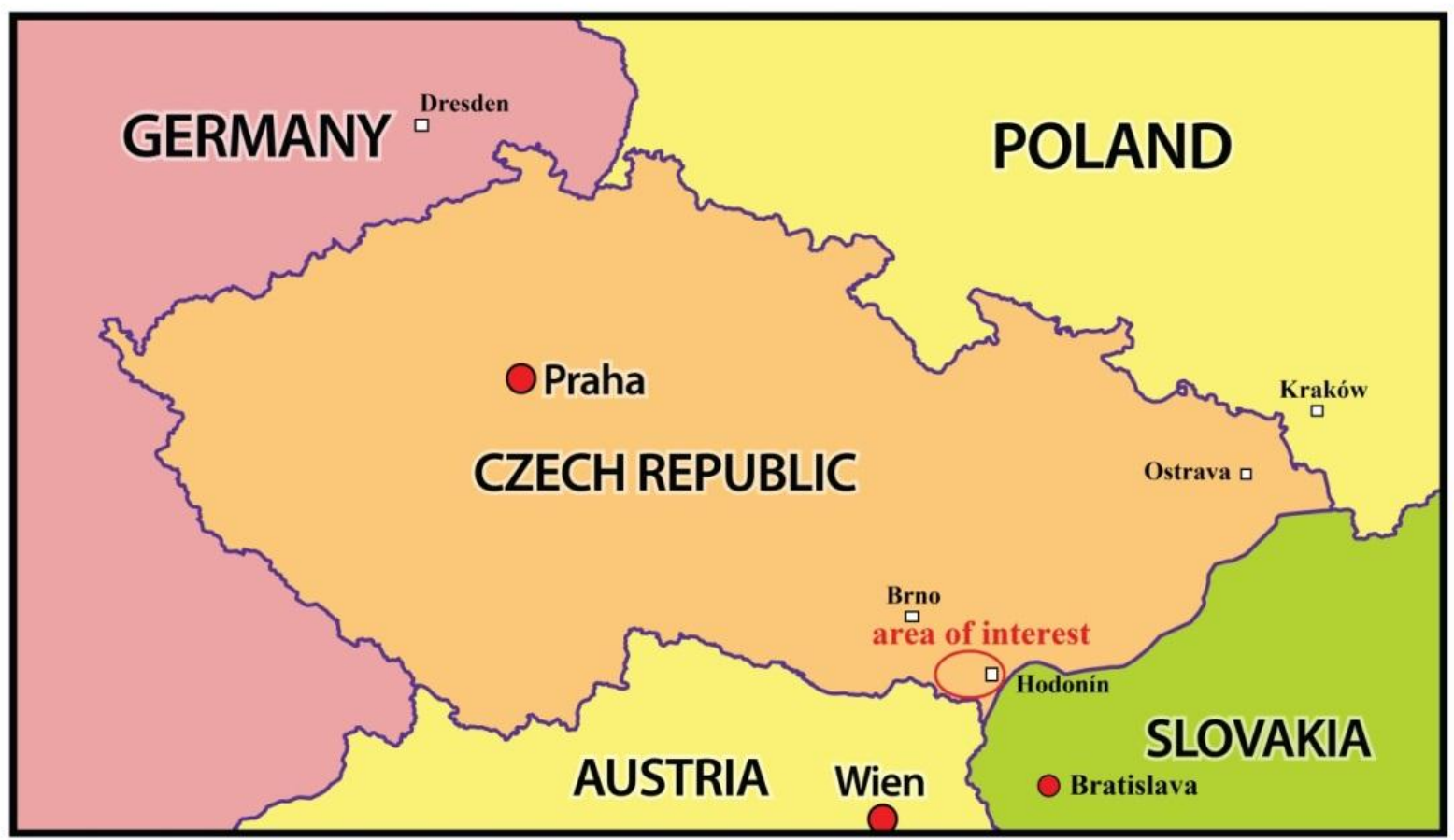

Fig. 1. The localization of the area of interest where the re-abandonment activities were carried out. (www.123digitalmaps.com)

\section{The Condition of the Old Oil and Gas Wells before the Re-abandonment}

The abandonment of production wells is a technically demanding task that requires large financial resources, proper technical equipment and often results in time consuming operation that deserves maximal attention. The major hazard in our case is the leakage of the formation fluids into the surficial layers (or surface eventually) where they contaminate groundwater and soil. In order to avoid such contamination the abandonment efforts focus on sealing possible leakage pathways that wellbore provides for the formation fluids. The main channels for fluid migration are the inside of the casing string, in the annulus of the wellbore and through uncased sections of the well.

The initial research of available archive materials led to the conclusion that the initial abandonments of the wells were not always successful and thus the existence of the oil leakage could be a real scenario (Fig. 2 suggests the possible formation fluid leakage pathways in our case). Such leaking state can be the consequence of several possible steps. For example when the primary cementation job was not conducted properly or commenced at all, the weak points suggest themselves. In the instance of backing-off the casing string above the cemented interval in the annulus and its complete or partial withdrawal, sections of the wellbore would be left open. The coincidence of this scenario with the questionable tightness of the cement plugs or casing string cementation leaves the hole in the unacceptable state of leakiness. The escape of formation fluids through wells with often unknown location to the surficial zones is presumably most intensive when there are no cement plugs at the top and/or bottom of the well and the casing is completely withdrawn from the borehole (Zeman, 2014; Robello, 2007; Sidorová, 2001; Stryczek, 2013).

Such potentially leaking well has to be re-abandoned and the operation has to be executed in accordance with the technical project which conforms to the Act of the State Mining Authority No. 239/1998 Coll. The re-abandonment job has to follow mining regulations and legal standards. 


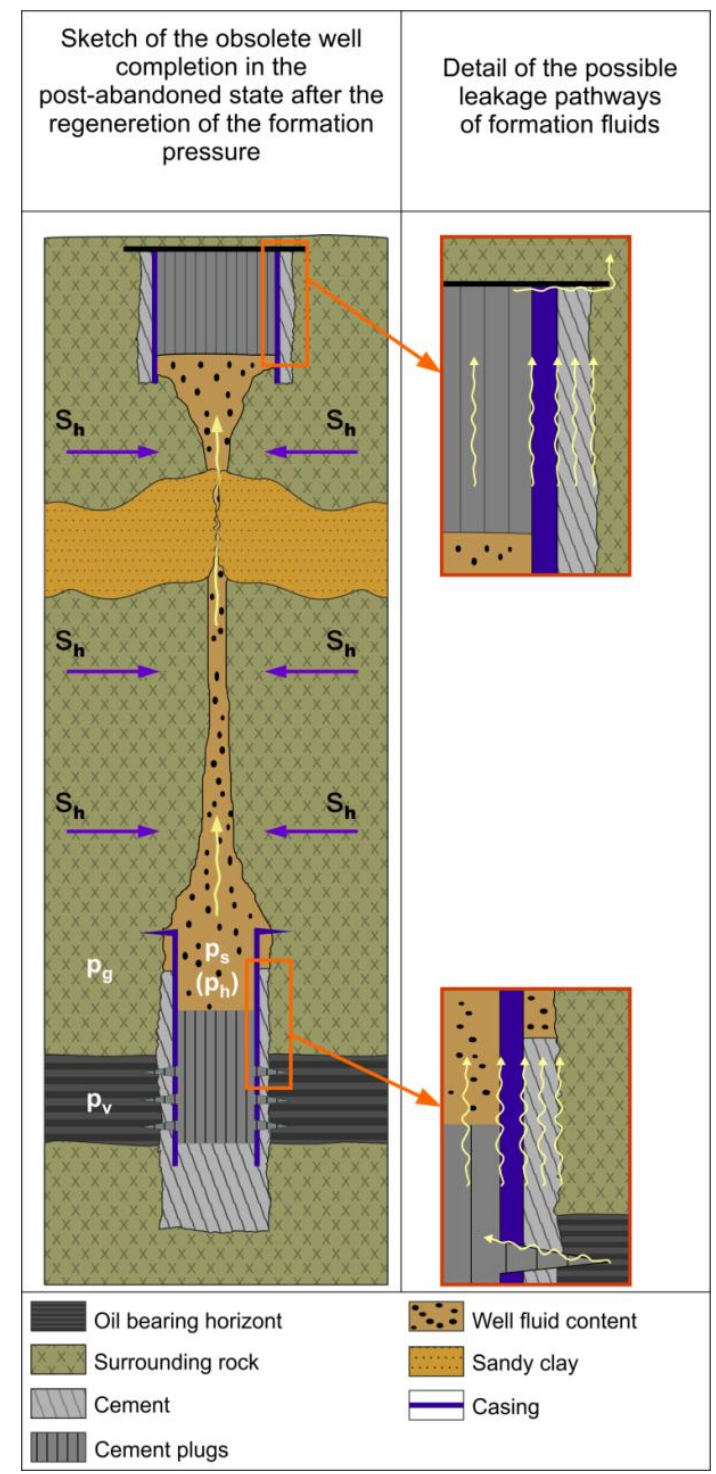

Fig. 2 The scheme of the condition of the wellbore before the definitive re-abandonment procedure (Sh - horizontal stresses around the wellbore; Pg - lithostatic pressure; Pv - formation pressure; Ps - well pressure; Ph - hydrostatic pressure) (Bujok, 2013)

\section{The Proposal of the Definitive Re-abandonment Procedure of the Old Oil and Gas Wells which have been Localized or Approximately Localized}

The old oil and gas wells that are in the focus of this paper are situated in the area that is high-profiled from the point of view of the water resources conservation. Proposals of the (not only) re-abandonment jobs in such areas must respect objections of all involved parities (i.e. civil service, local administration, protected areas administrators and watercourse administrators) and make the necessary efforts to meet the requirements of the Water Act No. 254/2001 Coll.

The old wells that are located precisely are re-abandoned conventionally which means that all necessary steps are undertaken in the original hole. However many archive records on wellbore positions are not precise and the wellheads cannot be located accurately. In order to deal with this kind of obstacle the alternative abandonment procedure was proposed in cooperation of the MND Drilling \& Services a.s. with the employees of the Faculty of Mining and Geology (under the VŠB-Technical University of Ostrava). The assumption behind this approach is that the archived coordinates 
have a limited inaccuracy due to the minor survey errors and the actual position of the well is in the vicinity of the recorded location. On the coordinates taken from archive well records is drilled another borehole that is considered to be parallel with the well under the re-abandonment process. In the selected formation superposing the productive horizons the hole is reamed, perforated and cemented under the pressure with the intention of making the "disc of cement slurry" which will intersect the original wellbore (see Fig. 3). The cement slurry will eventually invade the original hole and seal it so that the oil bearing formations will no longer hydraulically communicate with the surficial beds and surface at all. The laboratory verification of this method was carried out by the employees of the Institute of Geological Engineering and the Institute of Clean Technologies for Mining and Utilization of Raw Materials for Energy Use under the VŠB-Technical University of Ostrava.

The proposed procedure of re-abandonment of the well consists specifically of the following steps. In the selected interval for the pressure cementation (approx. on the level of $130-170 \mathrm{~m}$ under the surface) the cement bridge is formed. It consists of more than 1 ton of cement and small amount of $\mathrm{CaCl}_{2}$. Its quality is verified by putting 3 tons of WOB on it with drill string. In chosen formation above the cement is then perforated and subsequently flushed with the fresh water under the pressure. Thus disintegrated interval is afterwards filled through the cement retainer with more than $10 \mathrm{~m}^{3}$ of cement slurry with the pressure of $1.5-2.8 \mathrm{MPa}$ further disintegrating the formation and forming cement "disc". Another cement bridge is formed above the cement disc in order to abandon newly drilled cement injecting borehole. It is more than $100 \mathrm{~m}$ long and consists of cement and some amount of $\mathrm{CaCl}_{2}$ which is pumped under the 1 $\mathrm{MPa}$ pressure. Its quality is tested by putting $5 \mathrm{MPa}$ of WOB on it with drill string for 30 minutes. Another $20 \mathrm{~m}$ long cement plug is placed over this interval. The metal lid is eventually welded on the top of well $1.6 \mathrm{~m}$ under the surface. Applied casing string including its cementation has to be tested with the $5 \mathrm{MPa}$ pressure for 10 minutes interval for tightness.

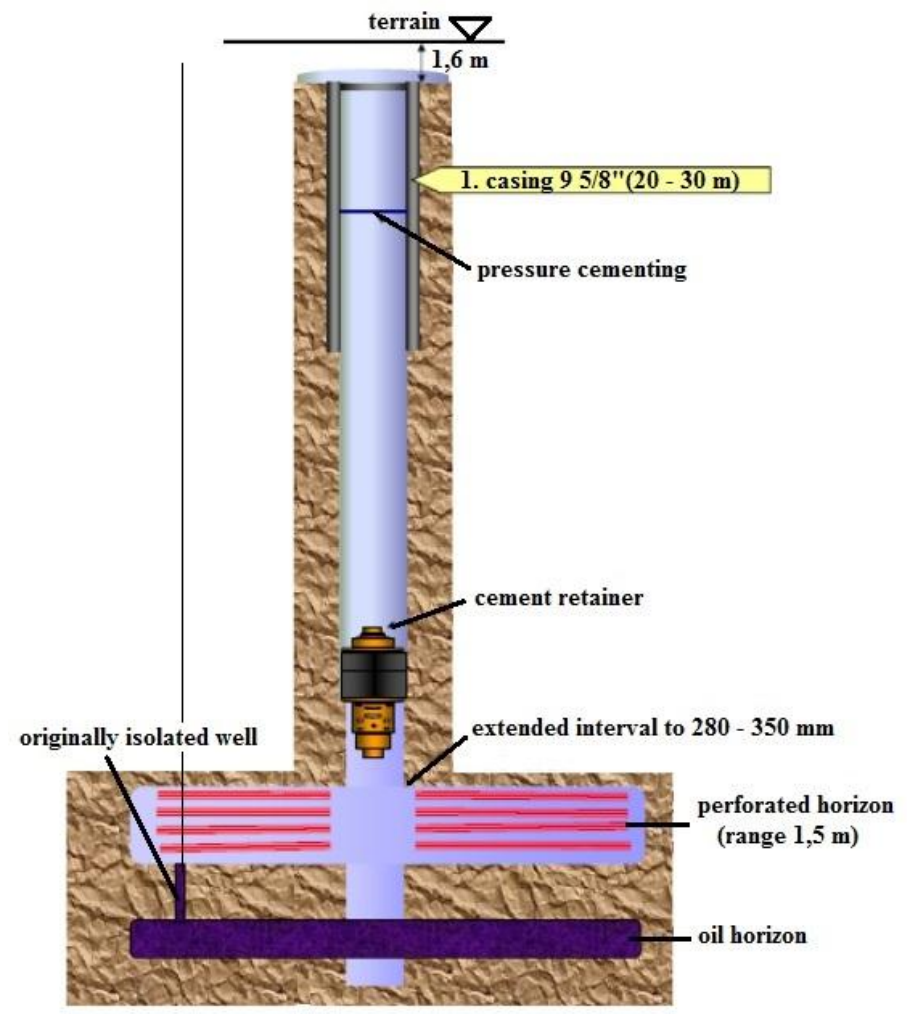

Fig. 3. Scheme of the proposed definitive re-abandonment procedure (Bujok, 2012; Guo, 2007) 


\section{The Laboratory Verification of the Proposed Definitive Re-abandonment Method of the Wellbores}

All rock samples used during the laboratory test were cored by the implementer of the method the MND Drilling \& Services a.s. Core samples were drilled in the pilot borehole H 111 from the depth of interest designed to fracturing (i.e. 118 - $120 \mathrm{~m}$ underground). Sampling preceded and succeeded the re-abandonment job described above. The semi-quantitative powder RTG diffraction of the samples showed that the formation consists mainly of the incoherent or poorly consolidated dolomitic and calcareous sandy and silty clay (Fig. 4).

Calcite
Dolomite
Microcline, intermediate1
Muscovite 1M
Plagioclase Albite
Quartz

$$
\begin{array}{r}
7.35+-2.16 \% \\
28.10+-4.20 \% \\
11.60+-4.50 \% \\
9.20+-3.90 \% \\
10.80+-3.30 \% \\
32.90+-3.30 \%
\end{array}
$$

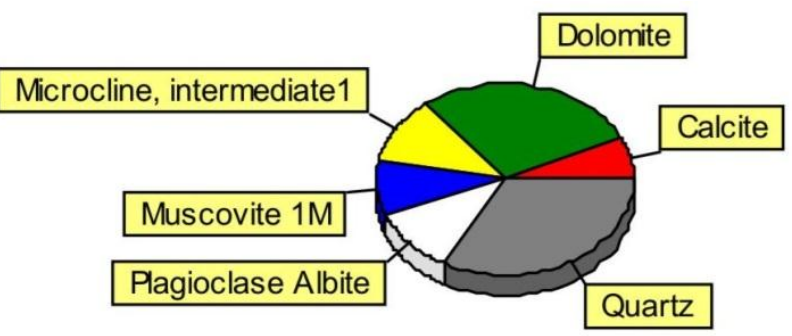

Fig. 4. Semi-quantitative analysis of a sample from a borehole $\mathrm{H} 111$

The compressive strength of the samples was evaluated with the MTS 816 Rock Test System instrument. This modern piece of equipment is fully automated and PC operated (see Fig. 5). Measurement results compressive strength on samples from the borehole H-111 are shown in Table. 1.

Table 1. Measurement results of compressive strength

\begin{tabular}{|l|c|c|c|c|c|c|c|c|}
\hline & $\begin{array}{l}\text { Side A } \\
{[\mathrm{mm}]}\end{array}$ & $\begin{array}{l}\text { Side B } \\
{[\mathrm{mm}]}\end{array}$ & $\begin{array}{l}\text { Side C } \\
{[\mathrm{mm}]}\end{array}$ & $\begin{array}{l}\text { Loading } \\
\text { Speed } \\
{[\mathrm{N} / \mathrm{s}]}\end{array}$ & $\begin{array}{l}\text { Maximum } \\
\text { Force } \\
{[\mathrm{N}]}\end{array}$ & $\begin{array}{l}\text { Pressure } \\
\text { Area } \\
{\left[\mathrm{mm}^{2}\right]}\end{array}$ & $\begin{array}{l}\text { Compressive } \\
\text { Strength } \\
{[\mathrm{MPa}]}\end{array}$ & $\begin{array}{l}\text { Rate of } \\
\text { Strain } \\
{[\mathrm{MPa} / \mathrm{s}]}\end{array}$ \\
\cline { 2 - 9 } & 52.87 & 49.26 & 50.74 & 1250 & 2031 & 2604.376 & $\mathbf{0 . 7 8}$ & 0.48 \\
& 52.83 & 51.98 & 50.76 & 1250 & 2030 & 2746.103 & $\mathbf{0 . 7 4}$ & 0.46 \\
& 50.76 & 52.14 & 52.54 & 1250 & 2252 & 2646.626 & $\mathbf{0 . 8 5}$ & 0.47 \\
& 51.03 & 50.08 & 50.81 & 1250 & 2516 & 2555.582 & $\mathbf{0 . 9 8}$ & 0.49 \\
\hline Average & 51.8725 & 50.865 & 51.2125 & 1250 & 2207.25 & & $\mathbf{0 . 8 4}$ & \\
\hline Deviation & 1.134207 & 1.421396 & 0.88549 & 0 & 230.8035 & & 0.128371 & \\
\hline
\end{tabular}

The permeability of samples was assessed using the MAF VII (apparatus developed by the employees of the Faculty of Mining and Geology), Benchtop Relative Permeameter 350 and automatic porosimeter and permeameter COREVAL 700 (both products of Vinci Technologies - France) (see Fig. 6). In order to observe the rock behaviour during its disintegration during the cement slurry pressure injection the testing container was developed for the experiments inside the pressure chamber. The testing container along with the testing procedure was suggested for the international intellectual property protection. 


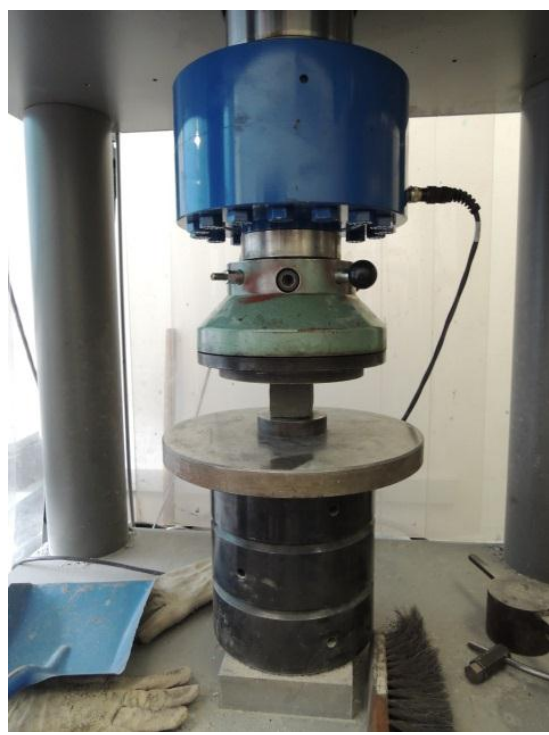

Fig. 5. Apparatus for evaluation of compressive strength

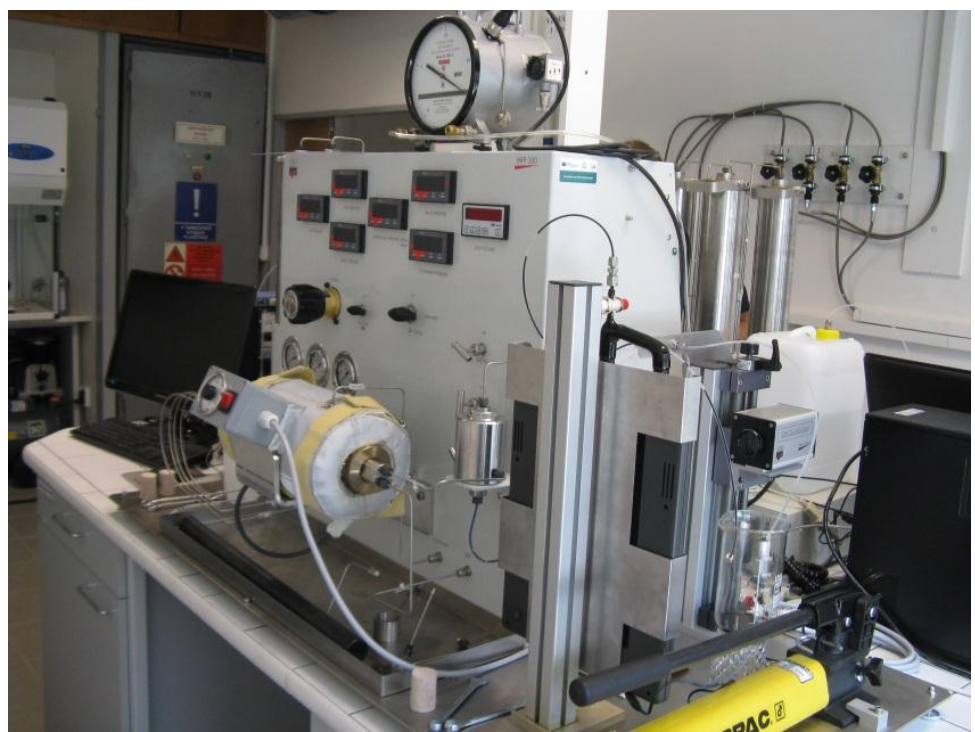

Fig. 6. Permeameter BRP 350

The high pressure apparatus RK-2 was utilized as a pressure chamber. It is a chamber of the RK line designed at the Institute of Geological Engineering that is usually utilized for permeability and improved/enhanced oil recovery experiments. It allows conducting the experiments at the pressure up to the $16 \mathrm{MPa}$ at the maximal temperature of $80{ }^{\circ} \mathrm{C}$ (Bujok, 2012).

Core samples were cut to get undamaged samples of the cylindrical shape. In the center of the cylindrical sample there was drilled a hole of $20 \mathrm{~mm}$ in diameter thereby simulating the rock environment surrounding the borehole. Samples prepared by explained method were placed into the pressure chamber (Fig. 7).

The simulation of the rock perforation process that determines the direction of the fractures could not be conducted in our conditions therefore experiments were reduced to the simulation of the fracturing process itself. During the fluid squeeze into the simulated wellbore the fractures started to propagate through the sample at the fluid pressures of $0.15 \mathrm{MPa}$ affecting the sample for just 2-3 seconds. The fractures were mainly of a vertical orientation (see Fig. 8 and Fig. 9).

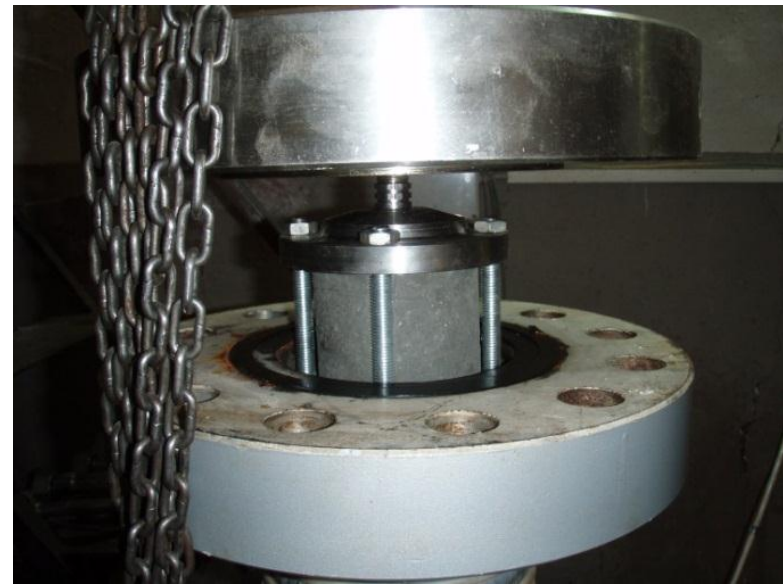

Fig. 7. Sample installation inside the pressure chamber with the testing container connected to the RK-2 lid by pressure line

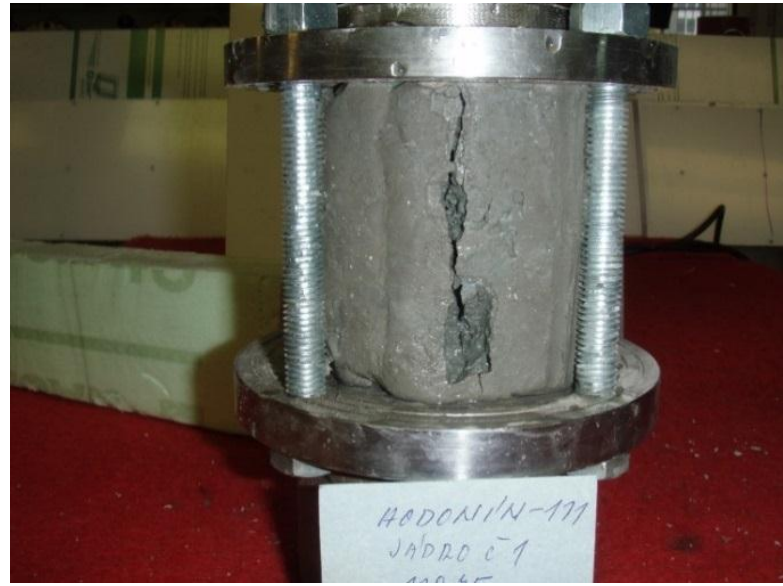

Fig. 8. Rock sample cored in $\mathrm{H} 111$ after the laboratory fracturing experiment - on the front face of the sample is apparent vertical fracture 


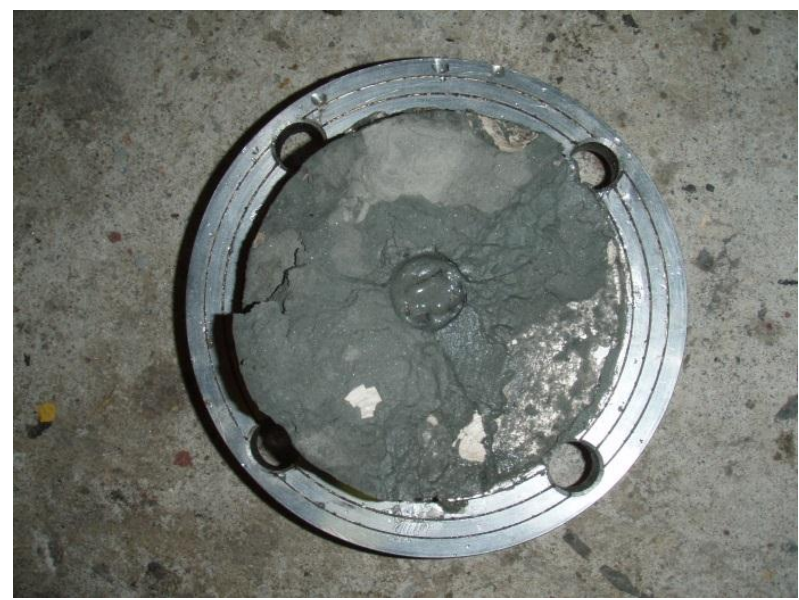

Fig. 9. Horizontal-vertical crack rock sample from the borehole $\mathrm{H} 111$ after test of fracturing

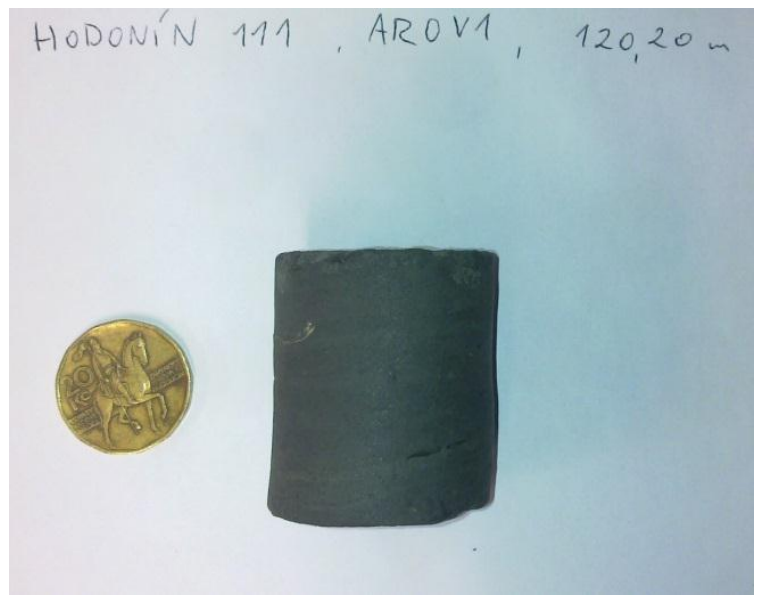

Fig. 10. Rock sample from control borehole $\mathrm{OV}_{1}$

The extent of the of the cement "disc" created during the fracturing field test at the borehole $\mathrm{H} 111$ was investigated with 4 boreholes (AR OV 1 to AR OV 4) drilled in the vicinity of the $\mathrm{H} 111$. The intervals of interest that were cored were in following distances from the H 111: OV $1-1.6 \mathrm{~m}$, OV $2-2.2 \mathrm{~m}, \mathrm{OV} 3-1.5 \mathrm{~m}$ and OV $4-1.8 \mathrm{~m}$.

On these cores were then re-determined compressive strength of collector and their properties. Due to the nature of the samples (Fig. 10) apparatus GPE 30 / Liqperm from Vinci Technologies Company was utilized. As an example, the results of measurements on the sample OV 1 from depth of $120.20 \mathrm{~m}$. The input parameters of the test are given in Table 2. Permeability was determined on a value of $0.1 \mathrm{mD}$. Test samples were evaluated as the liquid impervious for collector fluids (oil, deposit water).

Table 2. Input parameters of laboratory measurement $\left(\mathrm{N}_{2}\right)$

\begin{tabular}{|c|c|c|l|l|l|l|}
\hline $\begin{array}{l}\text { Length } \\
{[\mathrm{mm}]}\end{array}$ & $\begin{array}{l}\text { Diameter } \\
{[\mathrm{mm}]}\end{array}$ & $\begin{array}{l}\text { Weight } \\
{[\mathrm{g}]}\end{array}$ & $\begin{array}{l}\text { Lab. } \\
\text { Temperature } \\
{\left[{ }^{\circ} \mathrm{C}\right]}\end{array}$ & $\begin{array}{l}\text { Confining } \\
\text { Pressure } \\
{[\mathrm{MPa}]}\end{array}$ & $\begin{array}{l}\text { Inlet } \\
\text { Pressure } \mathrm{N}_{2} \\
{[\mathrm{MPa}]}\end{array}$ & $\begin{array}{l}\text { Outlet Pressure } \\
\text { (Atmosphere) } \\
{[\mathrm{hPa}]}\end{array}$ \\
\hline 47 & 39.3 & 114.91 & 22 & 2 & 0,66 & 896,3 \\
\hline
\end{tabular}

\section{Conclusion}

The samples were evaluated in the laboratory conditions for compressive strength and permeability. It was concluded that considering the petrological nature of the rock environment the formation of the brittle fractures system is unlikely. The rock is disintegrated, mixed with the cement suspension and pressed out in the form of thick "disc" into the surrounding area. The presence of this zone penetrated by cement was detected as far as $2.2 \mathrm{~m}$ of the $\mathrm{H} 111$ in a thickness of $65 \mathrm{~cm}$.

The outcomes of the field and laboratory experiments brought significant data which were used to adjust the reabandonment procedure. Finally, based on the laboratory analysis of the cored samples from the rock-cement "disc" around the $\mathrm{H} 111$ was concluded, that the rock-cement mixture displays convenient permeability character and that described method is therefore suitable for re-abandonment of the old wellbores which have uncertain location.

\section{Acknowledgements}

This article was written in connection with project Institute of clean technologies for mining and utilization of raw materials for energy use - Sustainability program. Identification code: LO1406. Project is supported by the National Programme for Sustainability I (2013-2020) financed by the state budget of the Czech Republic. 


\section{References}

Bujok, P.; Porzer, M.; Labus, K.; Klempa, M.; Pavluš, J. (2013): Experimental modelling of abandoned shallow oil wells convergence, Engineering Geology 157 (1-7), Elsevier B.V.

Bujok, P., Porzer, M., Klempa, M., Pavluš, J., Weiper, M., Selzer, L. (2012): Laboratory Verification of the Possibility of Communication between Reservoir Layer and the Surface, Through the Space of Improperly Abandoned Wells, in Case of Reservoir Pressure Buildup (in Czech). Report HS 541 202. Technical University of Ostrava.

Čižmář, Z. (2004): 90 let tradice Moravské naftové doly, Moravské naftové doly.

Durica, D.; Suk, M. (2011): Vrty v geologické praxi, Moravské zemské museum, Brno. ISBN 978-80-7028-381-3

Guo, B.; Lyons, W. C.; Ghalambor A. (2007): Petroleum production engineering - A computer-assisted approach, Gulf Publishing Company, Houston, Texas. ISBN 978-0-7506-8270-1

Robello, S.G., Xiushan, L. (2009): Advanced Drilling Engineering — Principles and Design. Gulf Publishing Company, Houston, Texas. ISBN 978-1-933762-34-0

Sidorová, M. (2001): Formation damage effects in a horizontal wells completion Acta Montanistica Slovaca, volume 6, special issue, pages 23 - 26. ISSN 1335-1788.

Stryczek, S.; Wisniowski, R.; Gonet, A.; Zlotkowski, A.; Ziaja, J. (2013): Influence of polycarboxylate superplasticizers on rheological properties of cement slurries used in drilling technologies, Archives of Mining Sciences, volume 58, issue 3. ISSN 08607001

Zeman, V.; Pinka, J.; Klempa, M.; Struna, J. (2014): Technika a Technologie vrtných prací - Základy technologie vrtných prací, II. díl. Marionetti Press, Ostrava. ISBN 978-80-905737-1-0.

www.123digitalmaps.com - map server, downloaded December 2014. 